\title{
A rare cardiac tumor presenting with myxoma: Primary cardiac hemangioendothelioma
}

\author{
Miksomaya eşlik eden nadir bir kalp tümörü: Primer kardiyak hemanjioendotelyoma

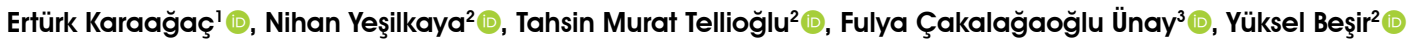 \\ Institution where the research was done: \\ İmir Katip Çelebi University Atatürk Training and Research Hospital, Izmir, Turkey \\ Author Affiliations: \\ 'Department of Cardiovascular Surgery, Muş State Hospital, Muș, Turkey \\ 2Department of Cardiovascular Surgery, İzmir Katip Çelebi University Atatürk Training and Research Hospital, lzmir, Turkey \\ ${ }^{3}$ Department of Medical Pathology, Izmir Katip Çelebi University Atatürk Training and Research Hospital, Izmir, Turkey
}

\begin{abstract}
Epithelioid hemangioendothelioma is a rare malignant vascular tumor which originates from the vascular endothelial or dendritic cells and has a moderate malignancy between benign hemangioma and malignant hemangiosarcoma, arising from vascular structures. Radical resection of epithelioid hemangioendothelioma is recommended, due to both its malignant nature and the adverse effects of associated complications on mortality and morbidity. In this article, we present a rare case of primary cardiac epithelioid hemangioendothelioma accompanied by a left atrial myxoma which was treated by resection.
\end{abstract}

Keywords: Cardiac, hemangioendothelioma, myxoma, primary, tumor.

Epithelioid hemangioendothelioma (EHE) is a rare malignant vascular tumor which originates from the vascular endothelial or dendritic cells and has a moderate malignancy between benign hemangioma and malignant hemangiosarcoma, arising from vascular structures. ${ }^{[1]}$ Although it was originally defined as a bronchoalveolar cell carcinoma of the lung by Dail and Liebowy ${ }^{[2]}$ in 1975, it was named EHE by Weiss and Enzinger $^{[3]}$ in 1982 due to its similar features. Similar to most of other primary intracardiac tumors, EHEs can be detected incidentally or based on the evaluation

\section{$\ddot{O} Z$}

Epiteloid hemanjioendotelyoma, vasküler endotelyal veya dentritik hücrelerden köken alan, benign hemanjiyom ile malign hemanjiyosarkom arasında orta derecede maligniteye sahip, vasküler yapılardan kaynaklanan nadir görülen malign bir vasküler tümördür. Epiteloid hemanjioendotelyomanın radikal rezeksiyonu, hem tümörün malign yapısı, hem de ilişkili komplikasyonlarının mortalite ve morbidite üzerine olumsuz etkileri nedeniyle önerilmektedir. $\mathrm{Bu}$ yazıda, rezeksiyon ile tedavi edilen sol atriyal miksomanın eşlik ettiği nadir bir primer kardiyak epiteloid hemanjioendotelyoma olgusu sunuldu.

Anahtar sözcükler: Kalp, hemanjioendotelyoma, miksoma, primer, tümör.

of the symptoms such as dyspnea, dysrhythmia, and angina pectoris or based on the presence of congestive heart failure, pericardial effusion, and thromboembolic events. ${ }^{[1]}$ Radical resection of EHE is recommended, due to both its malignant nature and the adverse effects of associated complications on mortality and morbidity.

In this article, we present a rare case of primary cardiac epithelioid hemangioendothelioma accompanied by a left atrial myxoma which was treated by resection.

Received: September 05, 2020 Accepted: November 05, 2020 Published online: January 13, 2021

Correspondence: Ertürk Karaağaç, MD. Muş Devlet Hastanesi, Kalp ve Damar Cerrahisi Kliniği, 49200 Muş, Türkiye.

Tel: +90 506 - 5870470 e-mail: erturkkaraagac@gmail.com 


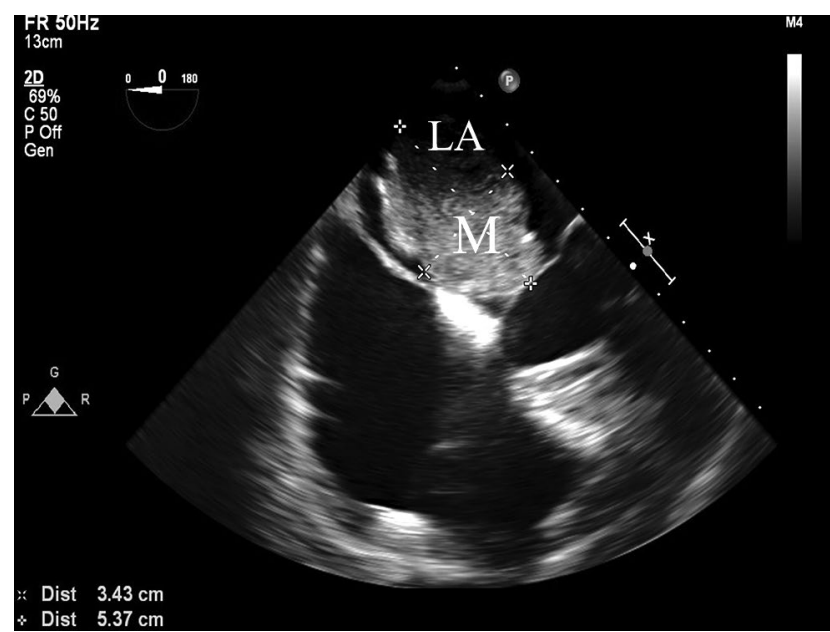

Figure 1. A transthoracic echocardiographic image of a myxoma. M: Myxoma; LA: Left atrium.

\section{CASE REPORT}

A 72-year-old female patient was admitted to our clinic with dyspnea and palpitation. Transthoracic echocardiography revealed a mass which was compatible with a myxoma originating from the left atrium and interatrial septum (about $3.4 \times 5.3 \mathrm{~cm}$ in size) (Figure 1) which caused stenosis and insufficiency of the mitral valve. Therefore, the patient was taken to operation for the purpose of myxoma resection. A written informed consent was obtained from the patient.

Median sternotomy and standard aortobicaval cannulation were performed. Cardiopulmonary bypass was initiated to evaluate the left atrium. Left atriotomy was performed and myxoma attached to the interatrial

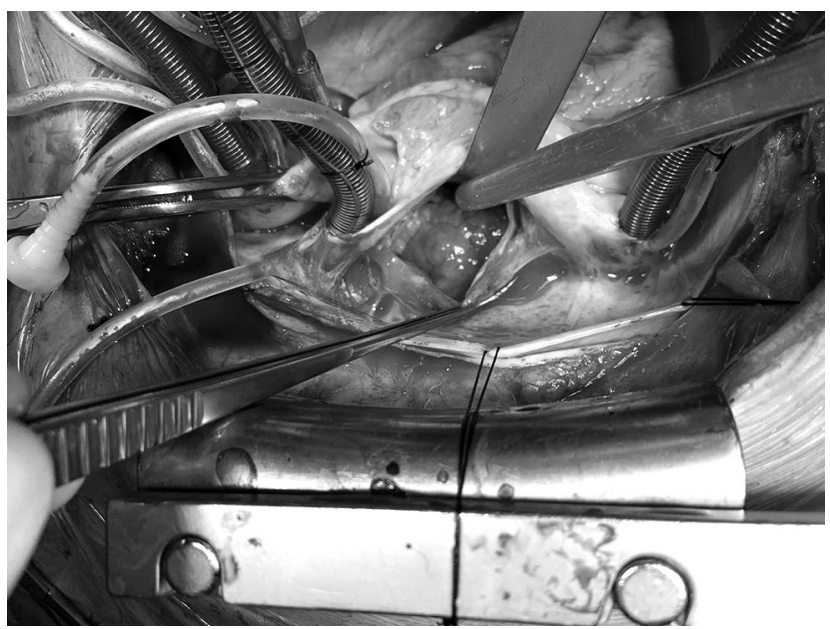

Figure 2. Left atriotomy was performed for myxoma resection and exploration of mitral valve.

septum by a stem was excised (Figure 2). When the mitral valve was evaluated, a solid tumor which was incompatible with a myxoma, was observed above the anterior leaflet. The mitral valve, whose leaflet movements were restricted due to this mass, was excised and sent to pathology for frozen-section examination. The result was reported as a stable sarcoma-like mass which was incompatible with a myxoma. Then, the mitral valve was re-evaluated, and the operation was terminated by replacing with the mechanical prosthesis valve, since it was not suitable for repair. Mechanical valve was favored, as the patient had to use warfarin anyway as a result of valvular atrial fibrillation. The patient was followed in the intensive care unit for two days and was discharged on Day 7 of operation.
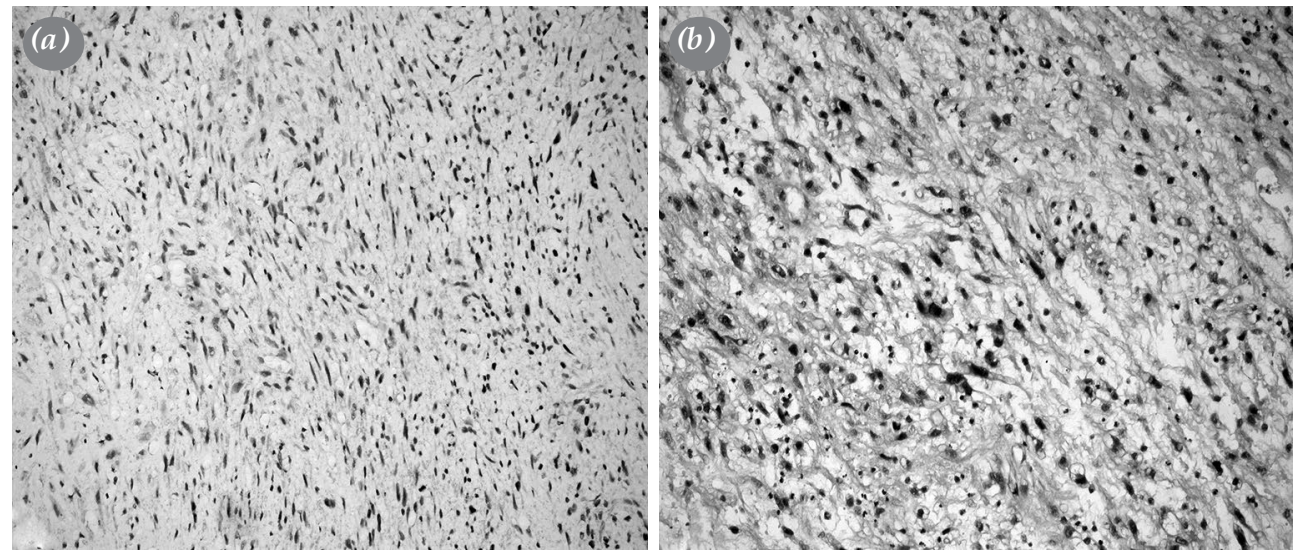

Figure 3. Evaluation of pathology samples in terms of desmin involvement and pleomorphism $(\times 20)$. (a) Desmin-negative result supporting the diagnosis of a primary cardiac epithelioid hemangioendothelioma is characterized by brown non-staining of the sample. (b) Primary cardiac epithelioid hemangioendothelioma is characterized by moderate pleomorphism, and atypically located cells and nucleus. 

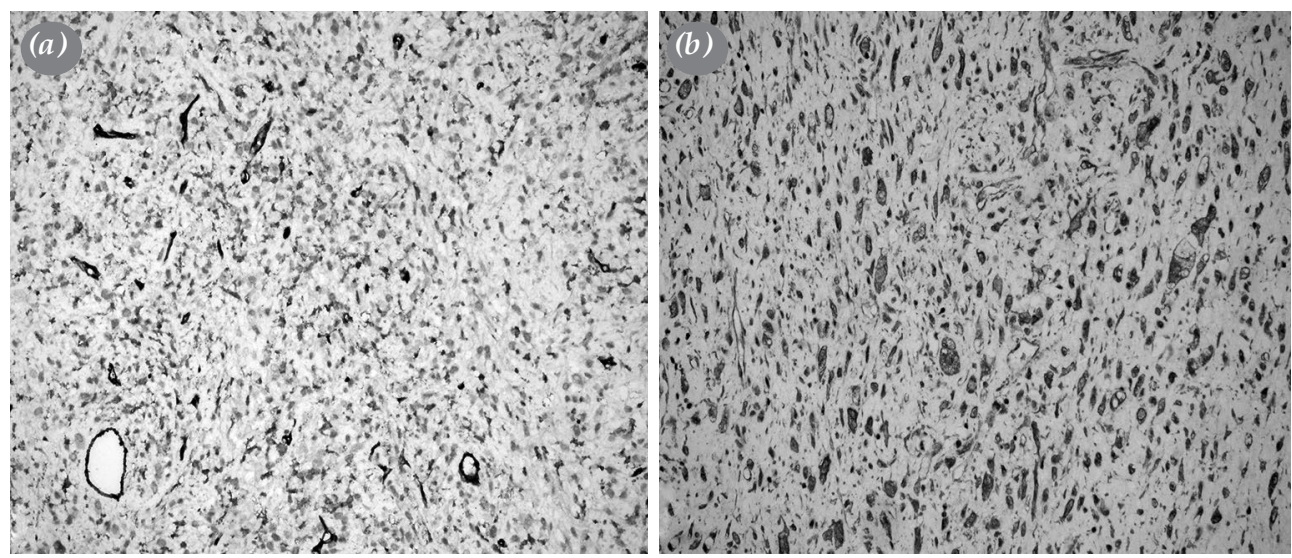

Figure 4. CD31-positive and vimentin-positive staining supporting the diagnosis of a primary cardiac epithelioid hemangioendothelioma $(\times 20)$. (a) CD31 staining is seen in a dense brown color. (b) Vimentin staining is seen in a dense brown color.

No residual mass was detected in the imaging studies at 6 and 12 months after the operation.

The following results were obtained in the postoperative immunohistochemical examination: Anti-cytokeratin clone, focal positive staining in a small number of cells; CD34, focal positive staining; CD68, negative staining; protein $\mathrm{S} 100$, negative staining; desmin, negative staining (Figure 3a); actin, negative staining. The diagnosis of myxoma was excluded based on these results. Also, the sample was interpreted as a low-grade vascular fibromyxoid mesenchymal heart tumor due to the positivity of CD31 (Figure 4a) and vimentin (Figure 4b). The patient was diagnosed with a primary cardiac EHE after positivity of Friend leukemia integration 1 transcription factor (FLI-1)

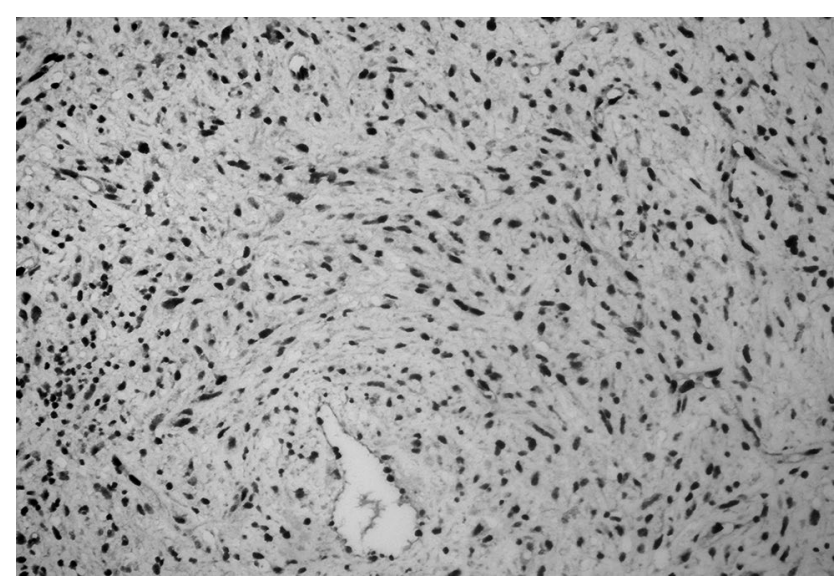

Figure 5. Friend leukemia integration 1 transcription factor-positive staining supporting the diagnosis of a primary cardiac epithelioid hemangioendothelioma in a dense brown color $(\times 20)$.
(Figure 5) and moderate pleomorphism (Figure 3b) were detected in the specimens.

\section{DISCUSSION}

It may be difficult to determine whether the tumor is multicentric or it is a primary lesion with metastases in other tissues, as EHE may originate from any organ and metastasize to the other, or it may involve more than one primary site. In some cases, it is possible to distinguish metastases from a multicentric primary tumor, due to their less differentiation and loss of the expression of epithelial markers such as FLI-1 and CD31. ${ }^{[4]}$ In our case, although there is no positron emission tomography imaging, we consider that this tumor could be a primary cardiac hemangioendothelioma due to differentiation of cells and expression of epithelial markers.

Intracardiac heart tumors are often metastatic and more rarely of a primary cardiac origin. Myxoma is the most common primary cardiac tumor and the most common benign cardiac tumor. ${ }^{[5,6]}$ The prevalence of primary cardiac tumors in the society ranges between 0.001 and $0.2 \% .{ }^{[7]}$ On the other hand, EHE is a rarer tumor with a millionth prevalence. ${ }^{[1]}$ Due to its rarity, the variety of cases reported in the literature is very limited. Although liver involvement is frequently observed in EHE, there are limited case reports of primary cardiac involvement. ${ }^{[8]}$

Primary cardiac involvement was firstly reported in 1979 by Hayward and Korompai ${ }^{[9]}$ and, in this patient, the tumor invading the mitral valve chordae was resected, and mitral valve repair was performed. In a case report by Lisy et al. ${ }^{[10]}$ EHE resection of a 
primary cardiac origin was presented and the authors concluded that EHE should be considered in tumors similar to myxomas, but atypically located. In our case, histological and immunohistochemical findings were consistent to the aforementioned report. In addition, some tumors which are located in the right or left atrium and have valve involvements are reported in the literature ${ }^{[8]}$ However, there is no case report in the literature that two intracardiac tumors with different origins are seen together. This coexistence of primary cardiac tumors, their malignant progression, and insufficiency of preoperative imaging once again demonstrate the importance of intraoperative evaluation.

In conclusion, although there was no atypical tumor location, we believe that diagnostic exploration of the heart chambers is important to the extent permitted by the surgical exposure in primary cardiac tumor surgeries.

\section{Declaration of conflicting interests}

The authors declared no conflicts of interest with respect to the authorship and/or publication of this article.

\section{Funding}

The authors received no financial support for the research and/or authorship of this article.

\section{REFERENCES}

1. Sardaro A, Bardoscia L, Petruzzelli MF, Portaluri M. Epithelioid hemangioendothelioma: an overview and update on a rare vascular tumor. Oncol Rev 2014;8:259.

2. Dail DH, Liebow AA. Intravascular bronchioloalveolar tumor. Am J Pathol 1975;78:6a-7a.

3. Weiss SW, Enzinger FM. Epithelioid hemangioendothelioma: a vascular tumor often mistaken for a carcinoma. Cancer 1982;50:970-81.

4. Gómez-Arellano LI,Ferrari-CarballoT, Domínguez-Malagón HR. Multicentric epithelioid hemangioendothelioma of bone. Report of a case with radiologic-pathologic correlation. Ann Diagn Pathol 2012;16:43-7.

5. Lam KY, Dickens P, Chan AC. Tumors of the heart. A 20-year experience with a review of 12,485 consecutive autopsies. Arch Pathol Lab Med 1993;117:1027-31.

6. Roberts WC. Primary and secondary neoplasms of the heart. Am J Cardiol 1997;80:671-82.

7. Reynen K. Cardiac myxomas. N Engl J Med 1995;333:1610-7.

8. Sugimoto T, Yamamoto K, Yoshii S. A Primary Epithelioid Hemangioendothelioma of the Right Atrium: Report of a Case and Literature Review. Open Journal of Thoracic Surgery 2013;3:63-7.

9. Hayward RH, Korompai FL. Endothelioma of the mitral valve. Ann Thorac Surg 1979;28:87-9.

10. Lisy M, Beierlein W, Müller H, Bültmann B, Ziemer G. Left atrial epithelioid hemangioendothelioma. J Thorac Cardiovasc Surg 2007;133:803-4. 